\title{
Samernas folkhögskola och de samiska språken 1942-1990
}

\author{
Johan Hansson
}

\begin{abstract}
The Sami folk high school and the Sami languages 1942-1990 • The Swedish Mission Society - SMS (Svenska missionssällskapet - SMS), wanted to improve the opportunities' for Sami youth in Sweden and therefore they started a folk high school (folkhögskola) for the Sami in 1942. One of the aims of SMS was to help the Sámi to preserve and develop the Sami culture and languages. Over time Sami themes, the languages being one, became more prominent at the school. However some of the problems regarding the language teaching remained: the students wanted to learn different Sami languages, their linguistic skills varied a lot, and there was not that many students who wanted to learn Sami. Despite these problems, the teaching improved over the years and the Sami folk high school remained important for the Sami people during the researched period.
\end{abstract}

Keywords • Sami [Samer], education [utbildning], identity [identitet], language [språk]

\section{Inledning}

Dig kan ingen ovän kuva, blott ditt väna språk du vårdar, minnes forntidsfädrens ma-

ning: Sameland åt samerna!

Strofen avslutar samernas nationalsång, Sámi soga lávlla (Samefolkets sång), antagen 1986 med text från $1906 .{ }^{1}$ Isak Sabas sång berör två inslag i många nationsbyggen, även det samiska: det egna språket och det egna landet. I slutet av 1800-talet kom statsmaktens inställning till de nordliga minoritetsspråken, finska och samiska, att förändras i samband med den nationaliseringsprocess som då inleddes. För den tornedalska minoriteten skapades ett metasystem där skilda system för utbildning samverkade. Denna samverkan var inte centralt samordnad, istället var institutionerna länkade till varandra genom bland annat gemensamma tankesystem och personliga relationer. ${ }^{2}$ En av de viktigare delarna i metasystemet var skolorna som skulle fostra svenska samhällsmedborgare. Bland dessa skolor fanns folkhögskolorna.

De svenskspråkiga folkhögskolorna i Tornedalen medverkade i hög grad i nationaliseringsprocessen genom att arbeta bort elevernas modersmål - finskan. ${ }^{3}$ Samhällets behandling av samer, tornedalingar och andra människor i norr var tämligen lika, men det fanns också skillnader. En av de mer betydande var att det för renskötande samers barn inrättades en särskild skolform: nomadskolan. Konsekvensen av den förändringen var att en grupp av samiska barn skildes från andra barn samt fick

1 I översättning av Arne Sörlie, "En sång - ett folk," http://www.samer.se/1149, Sápmi, 13 augusti 2015.

2 Lars Elenius, "Ett nationellt metasystem för utbildning och fostran i Tornedalen," Nordic Journal of Educational History $1 \mathrm{nr} 2$ (2014), 63-85, 68.

3 Elenius (2014), 68, 75.

Johan Hansson (PhD) is a Researcher in History and Education at the Department of Historical, Philosophical, and Religious Studies, Umeå University, Sweden.

Email:johan.hansson@umu.se

Nordic Journal of Educational History 2016. () Johan Hansson. This is an Open Access article distributed under the terms of the Creative Commons CC-BY4.0 License (http://creativecommons.org/licenses/by/4.0/). 
en skolgång där bara det nödvändigaste av kunskaper ingick. Precis som för barnen i Tornedalen så fick inte det egna språket användas i skolan, oavsett om de samiska barnen gick i folk- eller nomadskolan. ${ }^{4}$ Däremot fanns en skillnad i hur språkfrågan hanterades på folkhögskolorna.

Medan folkhögskolorna var viktiga delar i den apparat som skulle göra svenskar av tornedalingar, var situationen den omvända på de samiska folkhögskolorna i Sverige och Norge. I båda länderna startades folkhögskolor för samer i kristen regi. I Norge startade Norsk Finnemisjon år 1936 Den samiske ungdomsskole (DSU), i Sverige stod Svenska missionssällskapet (SMS) från år 1942 som huvudman för Samernas folkhögskola (SF). Vid starten var viljan att stödja eleverna i deras studier av samiska stor, och under i princip alla år bedrevs undervisning i något eller några samiska språk. En orsak till detta står att finna i de kyrkliga organisationernas långvariga arbete med att missionera på folkspråket, i detta fall samiska. En konsekvens av den idén var att det fanns personer kunniga i samiska språk knutna till organisationen sedan lång tid tillbaka. Dessutom startades Bodens folkhögskola, ett exempel på utbildningsinstitutioner i det metasystem som Lars Elenius beskriver, ungefär 50 år före SF och då rådde andra ideal inom svensk folkhögskola. ${ }^{5}$

Folkhögskolorna i Sverige liksom i de övriga nordiska länderna startades med de danska folkhögskolorna som förebilder. Inledningsvis betraktades folkhögskolorna som ett svar på behovet av utbildning för lantbrukare och därför startades det under 1800-talet flera folkhögskolor i Sverige i de regioner där jordbruket var starkt. Därefter startades folkhögskolor i andra delar av landet och vid sekelskiftet 1900 kom folkhögskolor även till städer och till landets nordligare delar. ${ }^{6}$ Folkhögskolornas inriktning förändrades så att de huvudsakligen kom att verka för medborgares allmänna bildning och gradvis blev folkhögskolorna tillgängliga även för kvinnor.7 Ytterligare en förändring var att rekryteringen till folkhögskolorna förändrades, liksom folkhögskolornas huvudmannaskap. I stället för unga bönder var det i stället arbetarklassens ungdomar som lockades till skolformen, och de flesta folkhögskolor som startades under 1900-talets första årtionden drevs av kristna organisationer. ${ }^{8}$ Under samma period kom den bildning som stod i centrum att förändras från att vara inriktad på nationen och den egna bygden till att vara mer internationell och samtidsinriktad. ${ }^{9}$ Folkhögskolorna var fria i vad deras utbildningar skulle innehålla, men de som tog emot statligt understöd var tvungna att följa folkhögskolestadgan.

Gemensamt för 1900-talets folkhögskolestadgor var att de reglerade undervisningen, anställningsregler och många andra frågor, men trots regelverket och statens inspektioner var friheten för folkhögskolorna stor. Folkhögskolestadgorna förändrades i takt med samhällets behov och förväntningar på folkhögskolan. Parallellt med ideal om bildning fanns tanken att folkhögskolan skulle vara av nytta för fortsatta

4 David Sjögren, Den säkra zonen: motiv, åtgärdsförslag och verksamhet $i$ den särskiljande utbildningspolitiken för inhemska minoriteter 1913-1962 (Umeå: Umeå universitet, 2010), 63f.

5 Elenius (2014), 74.

6 Hans Burgman, "Folkhögskolan och den pedagogiska utvecklingen 1968-1918," i Svensk folkhögskola 100 år, del 3, red. Allan Degerman och Paul Terning (Stockholm: Liber, 1968), 39.

7 Burgman (1968), 50-55, 61.

8 Paul Terning, "Folkhögskolan och den pedagogiska utvecklingen 1918-1968," i Svensk folkhögskola 100 år, del 3, red. Allan Degerman och Paul Terning (Stockholm: Liber, 1968), 22.

9 Terning (1968), 259. 
studier. ${ }^{10}$ Då SF startades år 1942 var målet att höja samernas utbildningsnivå samt att ge medborgerlig bildning, men även att hjälpa unga samer att bevara sitt språk och sin kultur. ${ }^{11}$ Denna utbildande verksamhet har inte undersökts i någon större utsträckning. ${ }^{12}$ Medan Elenius har beskrivit folkhögskolornas del i det system som verkade för tornedalingarnas fostran till att vara en del av den svenska kulturen samt att ha en svensk identitet, har SF:s betydelse för det samiska folkets identitet alltså inte studerats.

Den teoretiska utgångspunkten för undersökningen är att samer, liksom andra människor i Norden påverkats av en kolonial diskurs som får konsekvenser för identiteter och relationer mellan, och inom grupper i samhället. En sådan utgångspunkt ryms inom den postkoloniala teoribildningen för vilken Edward W. Saids Orientalism är en grundläggande del. Said beskrev Orientens funktion som motpol för Västerlandet och på så vis bidrog Orienten till västs självbild. ${ }^{13} \mathrm{Om}$ hänsyn tas även till andra strukturer, exempelvis klass och genus kan människors hanterande av sin situation förklaras ännu bättre. ${ }^{14}$ Med den utgångspunkten finns det möjligheter för olika förklaringar till individers och grupper av individers skilda upplevelser av vad som påverkar deras situation. Eftersom artikeln gäller samiskt språk och samisk identitet är tidigare studier av språk och identitetskonstruktion av betydelse.

För en människas identitet är språk betydelsefullt och genom språket tar vi till oss normer och värderingar. Beroende av de språk en individ behärskar kan en persons tankar om sig själv, sin grupp och sitt samhälle förändras. Detta gäller inte bara de språk som en person tagit till sig genom interaktion med familjemedlemmar. Även andra studier av språk medför en succesiv förändring av identiteten, och en individ blir genom språkkunskaperna delaktig i andra gemenskaper. ${ }^{15}$ Skolundervisning i minoritetsspråk påverkar elever som tar del av den, inte bara de som har minoritetsspråket som modersmål. I en spansk undersökning, med en enkätundersökning som huvudsakligt källmaterial, visade det sig att en undervisningsreform som tillät skolundervisning i katalanska påverkade alla elever. Även elever som inte hade katalanska föräldrar blev mer katalanska i sina attityder än vad som tidigare varit fallet. Samtidigt som språkundervisningen förändrades skedde också andra reformer och

10 Anna Larsson, Musik, bildning, utbildning: Ideal och praktik i folkbildningens musikpedagogiska utbildningar 1930-1978 (Göteborg: Makadam, 2007), 18-19; se även Statens offentliga utredningar (SOU) 1976:16, 41-47 för diskussionen om folkhögskolans uppdrag.

11 SMS syfte med sin folkhögskola beskrivs i artikelns bakgrundskapitel.

12 Se Johan Hansson, "Educational Activities at the Sami Folk High School 1942-1982," Creative Education 6, nr 9 (2015), 880-97; Johan Hansson, "Svenska Missionssällskapet och Samernas folkhögskola," i De historiska relationerna mellan Svenska kyrkan och samerna: En vetenskaplig antologi, red. Daniel Lindmark och Olle Sundström (Skellefteå: Artos, 2016).

13 Se Edward W. Said, Orientalism. (Stockholm: Ordfront, 2000).

14 Se Anna-Lill Ledman, Att representera och representeras: samiska kvinnor i svensk och samisk press 1966-2006 (Umeå: Umeå universitet, 2012), 29-33; Helena Tolvhed, "Intersektionalitet och historievetenskap," Scandia 76, nr. 1 (2010), 69; Stuart Hall, "När inträffade 'det postkoloniala'? Tänkande vid gränsen" i Globaliseringens kulturer: Den postkoloniala paradoxen, rasismen och det mångkulturella samhället, red. Chatarina Eriksson, Maria Eriksson Baaz och Håkan Thörn (Nora: Nya Doxa 1999), 84-86; Maria Carbin och Sara Edenheim, "The Intersectional Turn in Feminist Theory: A Dream of a Common Language," European Journal of Women's Studies 20, nr. 3 (2013), 245.

15 Dagmar Abendroth-Timmer och Eva-Maria Henning, "Plurilingualism and Multiliteracies: Identity Construction in Language Education," i Plurilingualism and Multiliteracies, red. Eva-Maria Henning och Dagmar Abendroth-Timmer (Frankfurt am Main: Peter Lang Publishing Group, 2014), 28. 
det kan inte uteslutas att även andra faktorer kan ha påverkat elevernas identiteter. ${ }^{16}$ Även i undersökningar av samiska identiteter visar det sig att språket är en viktig beståndsdel, men inte den enda.

Genom framför allt intervjuer har Christina Åhrén undersökt unga samers identitetsarbete. Utgångspunkten var att identitet är något som aktivt skapas i relation till andra, men inte nödvändigtvis i enlighet med individens egna önskemål. Rådande normer sätter ramarna för det individuella identitetsarbetet tillsammans med historien. ${ }^{17}$ Eftersom samer sedan lång tid bott på olika platser, livnärt sig på olika sätt och använt sig av olika strategier har olika kultursyner utvecklats och därmed olika samiskhet. Av alla faktorer som påverkat det samiska folket beskrivs de statliga reglerna kring rennäringen som allra viktigast för den rangordning bland samer som utvecklats. Åhrén beskriver denna ordning som en "samisk kulturstege där skilda individer tillskrivs olika värden utifrån sina kulturella kompetenser". Samtidigt som det finns ett yttre tryck från de som står utanför den egna folkgruppen finns det alltså ett ifrågasättande av en individs eller en grupps identitet inom det egna samiska folket. Denna situation förklaras med en stigmatisering av samer som medfört att det finns en nedvärderande attityd inom folkgruppen. Framför allt är det de grupper av samer som tidigare tonat ned sin härkomst för att nå fördelar i kontakt med majoritetssamhället som behandlas hårdast medan de som behållit vissa kulturella attribut står högst upp i denna sociala rangordning. ${ }^{18}$ Bland sådana attribut finns ursprungliga samiska namn, men även språkliga färdigheter och deltagande i traditionella samiska näringar som renskötsel påverkar positionen på den samiska kulturstegen. ${ }^{19}$

Utifrån den tidigare undersökningarna av språkets betydelse för identiteten samt forskningen om folkhögskolans betydelse för omformandet av minoriteters identitet blir denna artikels bidrag till forskningen följande: att genom studier av undervisningen i samiska på SF undersöka det samiska identitetsarbete som skedde i samband med folkhögskolans undervisning i samiska. Det preciseras i följande frågeställningar: Hur bedrevs undervisningen i samiska? I vilken mån förändrades undervisningen och av vilka orsaker skedde dessa förändringar? Kan ett samiskt identitetsarbete skönjas i samband med undervisningen i samiska språk vid SF och vilka uttryck tog sig i så fall ett sådant identitetsarbete?

\section{Forskningsmässiga överväganden}

Undersökningen avgränsas till perioden 1942 till och med 1990, eller snarare läsåret 1990-1991. Detta val motiveras av starten för SF samt 1990 års förändringar av folkhögskoleförordningen, något som året därpå påverkade förutsättningarna för SF:s verksamhet. ${ }^{20}$ Källmaterialet utgörs framför allt av skriftliga handlingar upprät-

16 Irma Clots-Figueras och Paolo Masella, "Education, Language and Identity," The Economic Journal 123, August (2013), 353-54.

17 Christina Åhrén, Är jag en riktig same?: En etnologisk studie av unga samers identitetsarbete (Umeå: Umeå universitet 2008), 14-17.

18 Åhrén (2008), 183-185, citatet från 185.

19 Åhrén nämner inte uttryckligen färdigheter i samiska som något inkluderande eller exkluderande, vilket däremot Vigdis Stordahl gör. Se Vigdis Stordahl, Same i den moderne verden: Endring og kontinuitet $i$ et samisk lokalsamfunn (Karasjok: Davvi girji 1996), 137. Se även Ledman (2012), 42-45.

20 Genom SFS 1991:977 upphörde det tidigare kravet om att ha allmän kurs för att få statsbidrag som folkhögskola. Det innebar att SF hade betydligt större friheter att med start läsåret 1991-1992 erbjuda undervisning med samisk kultur i centrum. 
tade vid SF, exempelvis korrespondens, undervisningsjournaler eller verksamhetsberättelser. Då det gäller perioden 1942-1972 har hela det arkiv som SMS lämnade efter sig studerats med undantag av sådant som inte direkt gäller undervisningen, exempelvis byggnadsritningar och dokument gällande försäkringar eller personalens pensioner. För den senare delen av undersökningsperioden, fram till och med läsåret 1990-1991 har valet av arkivmaterial varit snävare. Det har gällt framför allt planeringar, undervisningsjournaler och mötesprotokoll. Liksom för den tidigare perioden har sådant som inte direkt gällt undervisningen valts bort, exempelvis beslut angående renoveringar av byggnader. Arkivmaterialet har kompletteras med studier av litteratur gällande liknande skolverksamheter för unga samer i Norge. Texterna från Norge handlar om skolminnen publicerade i serien Samisk skolehistorie. Utöver detta skriftliga material har intervjuer genomförts. Informanterna har varit skolans rektorer under åren 1970-1990: Birgitta Östlund (1970-1976), Ingwar Åhrén (1976-1981), Per-Mikael Utsi (1981-1990). ${ }^{21}$ Intervjuerna har omfattat flera teman, däribland de samiska språken och språkens betydelse.

Intervjuer, liksom texter som behandlar händelser vilka utspelat sig en tid tillbaka för med sig källkritiska problem. Människors minne av en händelse tenderar att påverkas av de berättelser som traderas i ett större socialt sammanhang, i en familj eller i ett samhälle. Dessutom finns en tidsaspekt. Det är svårare att exakt minnas sådant som hänt för länge sedan än det som hänt nyligen. Informanters berättelser och nedtecknade skolminnen är trots dessa problem intressanta eftersom de är individuella tolkningar av händelser som utspelats. ${ }^{22}$ Intervjuerna har kunnat ge perspektiv på undervisning och övrig verksamhet som bedrevs på SF, perspektiv som inte kan erhållas genom skriftliga källor upprättade vid tiden. Urvalet betyder dock att elevperspektivet inte är särskilt framträdande och att det sällan är individuella uppfattningar som hörs. Vidare finns risken att då en enskild elev har kommunicerat med skolans rektor, exempelvis i brev, så har eleven på grund av sin beroendeställning inte nämnt de problem som upplevs. Detta gör att det i den föreliggande artikeln framför allt är skolledningens och lärarnas uppfattningar om de samiska språken och undervisningen i samiska på SF som undersökts.

Artikeln är disponerad så att efter en bakgrundsbeskrivning skildras den språkundervisning som bedrevs på SF i tre delar. Den första delen behandlar den period SMS var huvudman och de två andra stiftelsetiden. I ett sista avsnitt diskuteras de resultat som redovisats i de tre empiriska delarna.

\section{Bakgrund}

SF startade sin verksamhet i Sorsele 1942 med SMS som huvudman. Några år senare flyttades verksamheten till nybyggda och för verksamheten anpassade lokaler i Jokkmokk. ${ }^{23}$ Skolan bär sedan 1999 namnet Samernas utbildningscentrum (SU), och

21 Samernas utbildningscentrum, "Samernas" 70 år $i$ samernas tjänst: Jubileumstidning (Jokkmokk: Sámij åhpadusguovdasj, 2013), 25. Skolans förste rektor Lennart Wallmark är död sedan 1994. Ellen Saitton Burman fungerade som rektor under 1984-1985 men eftersom hon var vikarie under en kort tid har hon inte intervjuats. Intervjuer har också genomförts med rektorerna Nils-Henrik Sikku, Henric Mikael Kuhmunen samt Britt-Inger Tuorda, men dessa har inte använts i denna artikel eftersom de innehade rektorsposten efter undersökningsperiodens slut.

22 Lynn Abrams, Oral History Theory (London: Routledge 2010), 78-79, 105.

23 Lennart Wallmark, "Samernas folkhögskola, dess tillkomst och idé," i Bland Sveriges Samer: Årsskrift 1948-1949 (Umeå: Svenska missionssällskapet Kyrkan och samerna, 1949), 17-19. 
ambitionen är fortfarande att erbjuda samer en utbildning och en chans att förkovra sig i sin egen kultur, däribland de samiska folkens historia, slöjd och språk. SF/SU har sedan 1972 en stiftelse som huvudman och stiftelsen kontrolleras av Jokkmokks kommun och samiska organisationer. Såväl SF som SU har fått stora delar av sin finansiering genom stöd från statliga myndigheter, men även privatpersoner, stiftelser och organisationer har bidragit ekonomiskt. SF var inte tänkt som en skola med i huvudsak praktisk utbildning, utan skulle i stället förbereda för fortsatt utbildning exempelvis vid en yrkesskola. Likafullt hade renskötseln utrymme i undervisningen, bland annat genom studiebesök vid renskiljningar och lektioner om renbeteslagen.

Sex år innan SF inledde sin verksamhet startade den kristna organisationen Norsk Finnemisjon Den samiske ungdomsskole (DSU). Under den tyska ockupationen lades verksamheten ned för att åter starta 1947. Likheterna med SF var stora: huvudsaklig finansiering från staten, en religiös rörelse som huvudman, och en pastor som rektor. Det fanns även likheter gällande utbildningen som även vid DSU var koncentrerad till allmänna teoretiska skolämnen. I både Norge och Sverige saknades undervisning i samiska på skolor för samiska barn, något som de båda folkhögskolorna erbjöd samiska ungdomar. Likheterna mellan skolorna var stora, men medan SMS lämnade sitt huvudmannaskap i början av 1970-talet behöll Norsk Finnemisjon sitt ända till år 1985 då DSU år 1985 lades ned på grund av ett allt för litet elevantal. ${ }^{24}$ Vad det gäller praktiska utbildningar för samer så fanns i Norge kurser i renskötsel avsedda för samiska ungdomar redan på 1950-talet. ${ }^{25}$ Mer omfattande utbildningar för renskötsel startade på 1960-talet med norska som det huvudsakliga undervisningsspråket, trots att många elever inte behärskade majoritetsspråket. ${ }^{26}$ Under 1950-talet startades yrkesutbildning för samer vid Heimeyrkeskolen i Kautokeino. Starten var en slöjdutbildning med olika inriktningar och andra utbildningar tillkom därefter. Ambitionen var att skolan skulle ge en yrkesutbildning, men också att bevara den samiska kulturen samt ge eleverna förståelse för den egna kulturens värde. Trots det kom undervisningstiden i norska att öka samtidigt som samiskan tilldelades ett minskande utrymme i elevernas schema för att helt utgå under några år under 1960-talets början. Under läsåret 1964-1965 fanns samiska åter i timplanen. ${ }^{27}$ Trots de ursprungliga ambitionerna fick inte heller andra delar av den samiska kulturen och de samiska näringarna något nämnvärt utrymme i undervisningen under de år som följde. Eleverna var inte nöjda med situationen och framförde genom sin elevorganisation bland annat krav på läroböcker på samiska år 1975. Gradvis skedde förändringar av de olika yrkesutbildningarnas innehåll så att de fick ett lärostoff mer

24 Hans Lindkjølen, "Kirkens rolle i samisk opplæring," i Samisk skolehistorie: Artikler og minner fra skolelivet i Sápmi 1, red. Svein Lund, Elfrid Boine och Siri Johansen (Karasjok: Davvi girji, 2005), 48-50, 54.

25 Bjørn Aarseth, "Forsøk med reindriftsfag i skolen”, i Samisk skolehistorie: Artikler og minner fra skolelivet i Sápmi 2, red. Svein Lund, Elfrid Boine och Siri Johansen (Karasjok: Davvi girji, 2007), 46.

26 Svein Lund, "'Den aller største milepær i næringens historie,” i Samisk skolehistorie: Artikler og minner fra skolelivet i Sápmi 2, red. Svein Lund, Elfrid Boine och Siri Johansen (Karasjok: Davvi girji, 2007), 66, 74.

27 Svein Lund, "'Den eneste i sitt slag i hele verden," i Samisk skolehistorie: Artikler og minner fra skolelivet i Sápmi 2, red. Svein Lund, Elfrid Boine och Siri Johansen (Karasjok: Davvi girji, 2007), , 114-41. 
anpassat för samiska behov. Även de samiska språkens plats i skolans verksamhet förändrades och sedan 1989 skulle undervisningen huvudsakligen ske på samiska. ${ }^{28}$

Idag finns det i Sverige en gymnasieskola, Bokenskolan i Jokkmokk, som har två samiska program, ett praktiskt och ett teoretiskt. Båda programmen har undervisningsinslag i samarbete med Samernas utbildningscentrum och i båda programmen finns möjlighet att studera samiska. Medan det praktiska programmet Samiska näringar har exempelvis rennäring i centrum är det teoretiska programmet mer att likna vid det vanliga samhällsvetenskapliga programmet, men med samiska inslag. Bokenskolans norska motsvarighet är Samisk videregående och reindriftskole i Karasjok. Dess yrkesförberedande program har som tidigare nämnts funnits sedan 1950-talets början medan den studieförberedande utbildningen tillkom $1969 .^{29}$ Trots de många reformerna av utbildningssystemet i Sverige var det först i och med 2011 års gymnasieskola (Lgy 11) som det samiska praktiska programmet lanserades. 1994 års gymnasieskola (Lpf94) skapade dock möjligheter till lokala anpassningar och specialprogram, och därmed kunde det något förändrade samhällsvetenskapliga programmet ges från och med läsåret 1994-1995. Dessförinnan var alltså SF, eller någon av de norska skolorna de alternativ som fanns för den som hade intresse för en samiskt präglad utbildning.

I denna utveckling var samiska organisationer i hög grad medverkande. Men även utanför Svenska Samers Riksförbund (SSR), Same Ätnam och andra etablerade samiska organisationer fanns aktivitet som påverkade samisk politik och därmed även utbildningsmöjligheter för samer. De strömningar i samhället som påverkade politiken i västvärlden nådde det samiska samhället i 1960-talets slut. Under perioden var engagemanget mot Vietnamkriget stort och den vänstervåg som svepte genom samhället påverkade framför allt ungdomar till att engagera sig $i$ olika radikala rörelser. Inte bara protesterna mot Vietnamkriget engagerade, även rörelser för minoriteters rättigheter som vuxit fram i andra delar av världen under 1950- och 1960-talen uppmärksammades. De mest kända är förmodligen USA:s medborgarrättsrörelse, Black Panther Party (BPP) och American Indian Movement (AIM). Den samlade medborgarrättsrörelsen arbetade främst för svartas rättigheter genom olika typer av civilt motstånd. AIM:s verksamhet gällde de amerikanska urfolkens rättigheter och de belyste bristerna i dessa genom spektakulära aktioner. AIM samarbetade med ett flertal organisationer i Nordamerika, men arbetade även med urfolk i andra delar av världen. Nordamerikas minoriteter och deras aktivism var inspirerande för de unga samer som ville ha en snabb förändring av samhället och den egna situationen. Det som skedde i Nordamerika under 1960- och 1970-talet visade att ett politiskt arbete kunde ge resultat även om det skedde utanför de etablerade politiska partierna.

Någon samisk variant på AIM startades inte, men delar av den samiska aktivismen under 1970-talet och 1980-talet hade vissa likheter med det som skedde i USA.

28 Brev från elever till skolledningen 31/1 1983, "Elever krever obligatorisk samisk," tryckt i Samisk skolehistorie: Artikler og minner fra skolelivet i Sápmi 2, red. Svein Lund, Elfrid Boine och Siri Johansen (Karasjok: Davvi girji, 2007), 172; Svein Lund, "Fisk på land - ein dáža i samisk skole," i Samisk skolehistorie: Artikler og minner fra skolelivet i Sápmi 2, red. Svein Lund, Elfrid Boine och Siri Johansen (Karasjok: Davvi girji, 2007), 176, 180, 188, 190.

29 "Glimt fra kampen om samisk gymnas," tryckt korrespondens i Samisk skolehistorie: Artikler og minner fra skolelivet i Sápmi 2, red. Svein Lund, Elfrid Boine och Siri Johansen (Karasjok: Davvi girji, 2007), 202. 
Förmodligen är försöken att hindra vattenkraftverksutbyggnaden vid Alta i Norge mellan åren 1978 och 1982 de mest betydelsefulla. I förlängningen påverkade dessa händelser den norska inrikespolitiken och lade grunden för bland annat inrättandet av det norska Sametinget. ${ }^{30}$ Alta-aktionen pågick under lång tid och innehöll element som civil olydnad samt ett misslyckat bombattentat. Aktionen fick stort massmediautrymme och påverkade majoritetsbefolkningens uppfattningar om samer i positiv riktning. I sådan måtta är den att likna vid AIM:s aktioner. Alta-aktionen gällde frågor om hur möjligheter till ett traditionellt samiskt liv påverkas av ingrepp i naturen. Språkfrågan var inte central i Alta-konflikten, men ungefär vid samma tid var ČSV-rörelsen aktiv, och i det sammanhanget var språket av största betydelse.

ČSV är ofta nämnd eller kommenterad, men inte grundligt vetenskapligt studerad. ${ }^{31}$ Den vanligaste beskrivningen av rörelsens uppkomst gör gällande att inledningen var ett litteraturseminarium i Norge år 1972, det land där ČSV var mest framträdande. Beskrivningarna av ČSV brukar skildra en aktivism för att öka samers stolthet för sin etniska tillhörighet, sitt språk och sin kultur. Den exakta betydelsen av ČSV anses vara oklar, men vanliga uttydningar av förkortningen är Čájehehkot Sámi Vuoinnja eller Čielga Sámi Varra (Vis samisk ande respektive Rent samiskt blod). I beskrivningarna av ČSV brukar också sägas att rörelsen bidrog till att skapa en god samisk självbild och en känsla av att det är möjligt att påverka sin situation. Även ČSV-rörelsens gränsdragning mellan samer och majoritetsbefolkning genom samiska identitetsmarkörer som språk eller kläder brukar påtalas. ${ }^{32}$ I berättelserna om ČSV ingår inte exempel på att någon ska ha upplevt sig ha blivit utdefinierad från en samisk gemenskap, eller på annat sätt negativt behandlad. Det utesluter inte möjligheten att det bland de som identifierade sig som samer, men exempelvis inte behärskade språket eller saknade möjlighet att utöva de traditionella näringarna kan ha funnits sådana erfarenheter. ${ }^{33}$

\section{Samiska språk på SF med SMS som huvudman, 1942-1972}

"Edert språk med sina skilda munarter är i sin egendomlighet och rikedom likaledes en Skaparens gåva, som icke bör förslösas" skrev biskop Bengt Jonzon i den broschyr som beskrev den tänkta utbildningen vid SF år 1942. Jonzon förklarade att syftet med folkhögskoleutbildningen var att ge eleverna allmän bildning, en chans att bevara den samiska kulturen och att utveckla den, förbättra möjligheterna för individen att göra en insats för sitt folk, samt att genom att vara just samer bidra till

30 "Ville bruke soldater i Alta-aksjon," Aftenposten, 19 oktober, 2011, http://www.aftenposten.no/nyheter/iriks/Ville-bruke-soldater-i-Alta-aksjon-6393917.html.

31 En av få tillgängliga uppsatser på temat är Coppélie Cocq, Mobilisering av minoritetsfolk: ČSV en etno-politisk rörelse bland samerna, jämförelse med négritude, en rörelse bland afrikaner (Umeå: Umeå universitet, 2000).

32 Se exempelvis Ledman (2012), 80; Åhrén (2008), 63-64; Ivar Bjørklund, Sápmi - Becoming a Nation: The Emergence of a Sami National Community (Tromsø: Tromsø museum 2000), 28-31, 3841.

33 ČSV nämns inte uttryckligen av Åhrén då hon diskuterar den samiska etnocentrismen. Denna etnocentrism grundar sig i kulturskillnader och symboliska gränser, olikheter som förklaras med en historieskrivning där "lapp ska vara lapp"-politik och renskötselfrågor ingår. I förklaringen ingår även det aktiva arbetet att förstärka och bevara den samiska identiteten, något som gjort att de som har många samiska attribut framstår i mer positiv dager än de som tidigare försökt tona ned sitt samiska arv. Åhrén (2008), 183-86. 
det svenska samhället. Kristen kunskap och karaktär hade en viktig plats i Jonzons beskrivning, men även samiskan. SF beskrevs som en skola som "skulle särskilt ägna uppmärksamhet åt samernas språk, historia, kultur och yrkesliv..." ${ }^{44}$ Den undervisning som Jonzon, och även den blivande rektorn Lennart Wallmark, gav uttryck för i broschyren kom aldrig att realiseras i sin helhet, men skolledningen arbetade för att åstadkomma en god undervisning i samiska språk.

Under SMS-åren var eleverna få och ekonomin var därmed knapp. ${ }^{35}$ Antalet lärare varierade mellan åren, men som regel var endast två av dem tillsvidareanställda: rektorn och ytterligare en lärare. Den andre läraren undervisade främst i allmänna skolämnen, till exempel matematik. Kunskaper i samiska språk kom i stället från de timanställda lärarna, sällan anställda under mer än något enstaka läsår vilket gjorde att den språkliga kompetens som eleverna mötte var varierande. Dessutom kunde elever och lärare komma från olika språkområden, och elevernas kunskaper i samiska varierade. Vissa läsår kunde elever ha "vanlig" undervisning av en lärare kunnig i samiska, men ofta organiserades undervisningen som studiecirklar. Cirkelledaren var inte nödvändigtvis en person med ett samiskt språk som modersmål, Wallmark var själv cirkelledare ibland. Bland annat var situationen för eleverna under 19441945 sådan att de kunde studera samiska genom en kurs där många gästlärare medverkade och som spände över exempelvis "Vilhelminalapska" och "Härjedalslapska". Under den vintern arrangerades även en studiecirkel i "Lulelapska" under ledning av rektor Wallmark och Dagmar Norrby, en av de svenskspråkiga timlärarna. ${ }^{36}$ Under vinterkursen 1950-1951 gavs endast lulesamiska, men då som kontinuerlig lärarledd undervisning. ${ }^{37}$ 1955-1956 ordnades studiecirklar i nord-, lule- respektive sydsamiska. Dessa var ledda av lärare och omfattade två veckotimmar vardera. Cirkelledare var Wallmark, Nikolaus Kuhmunen och Henrik Sandberg med bistånd av Harald Grundström, Israel Ruong, och Karin Stenberg. Även elever med särskilda kunskaper i något av de samiska språken bidrog till sina kamraters lärande. ${ }^{38}$ Det faktum att lärarens språkkunskaper ibland var bristande innebar att elevernas eget ansvar för sina egna språkliga studier blev stort. De gästlärare som var kunniga i samiska förbättrade vissa år kvaliteten avsevärt, men omfattningen av exempelvis språkvetarna Ruongs och Grundströms deltagande varierade mellan åren.

Lärostoff, läromedel och arbetssätt kommenterades inte utförligt i undervisningsjournaler och årsredovisningar. Exempelvis skildrades undervisningen i samiska under läsåret 1968-1969 på följande sätt:

Läroböcker: K.B Viklund: Lulelapska. Harald Grundström: Lulelapsk ordbok. Texter utarbetade av Olavi Korhonen. Grupp A: Vad är lapska språket? Wiklunds lärobok i lulelapska, styckena 1-7 genomgångna med grammatiska tillämpningsövningar.

34 Bengt Jonzon, "Till Sveriges samer," i Svenska missionssällskapet, Samernas folkhögskola (Luleå: Svenska missionssällskapet, 1942), 3-4.

35 Fram till 1968 var alla elever samer.

36 Lennart Wallmark, Samernas folkhögskola: Sorsele: redogörelse för läsåret 1944-1945 (Jokkmokk: Svenska missionssällskapet, 1945), 12.

37 Lennart Wallmark, Samernas folkhögskola: Jokkmokk: redogörelse för läsåret 1950-1951 (Jokkmokk: Svenska missionssällskapet, 1951), 8.

38 Lennart Wallmark, Samernas folkhögskola: Jokkmokk: redogörelse för läsåret 1955-1956 (Jokkmokk: Svenska missionssällskapet, 1956), 11-12. 


\begin{abstract}
Lapska ortsnamn enligt Professor Björn Collinder och Nils-Eric Spiic. Lapska benämningar på trummans symboler och figurer. Jämförelse mellan lule- och nordlapska med texter av Olavi Korhonen. Lapska kultord. Finska och Lapska - en jämförelse. (1 vt. L. Wallmark, Olavi Korhonen).
\end{abstract}

Grupp B: Läsning, översättning och grammatik. Skrivningsövningar. Lapska ortsnamn (1 Vt. Nils-Eric Spiic) ${ }^{39}$

Eleverna delades som regel in i grupper beroende på deras förkunskaper eller språktillhörighet. Så gjordes även i Engelska och Tyska. Under läsåret 1968-1969 förefaller däremot inte eleverna ha delats in efter vilket samiskt språk de ville lära sig. Förutom att Wallmark mer sällan fungerade som cirkelledare innebar 1960-talet inga större avvikelser från tidigare upplägg. I stället för rektorn fick eleverna möta lärare som var mer förtrogna med de samiska språken. ${ }^{40}$

Trots den betydelse som skolledningen fäste vid samiskan och ökande möjligheter att anställa språkkunniga lärare tilldelades de samiska språken endast en liten andel av undervisningstiden. Under 1965-1966 års vinterkurs ägnades totalt 47 timmar åt undervisning av samiska, medan sameslöjd gavs i 167 timmar och engelska i 234 timmar. Läsåret 1968-1969 hade engelskan utökats till 254 timmar medan samiska bara gavs i 44 timmar. Ett år senare gavs engelska i 162 timmar medan lärarna undervisade totalt 40 timmar i samiska. ${ }^{41}$ De år som både engelska och samiska gavs ägnades alltså mer tid till engelska. Detta berodde främst på de krav som fanns på SF i egenskap av statligt stödd folkhögskola - krav på allmän linje. SF var ursprungligen endast öppen för samer och i ett försök att öka elevantalet tilläts även icke-samer från och med 1968. Läsåret 1968-1969 studerade 44 elever vid skolan, varav 17 samer. Ett år senare gick 41 elever på skolan, men bara nio var samer. ${ }^{42}$ Trenden med ett för litet elevantal och en allt mindre andel samiska elever gjorde att skolans verksamhet omorganiserades och huvudmannen byttes ut. Processen inleddes i slutet av 1960-talet, men kom till sin ände under Birgitta Östlunds tid som rektor. Under hennes första tid på SF kom en stiftelse med samisk representation att ta över från SMS, något som fullbordades 1972 .

\title{
Samiska språk under perioden 1972-1981
}

Under det tidiga 1970-talet kom alltså ett skifte i huvudmannaskapet. Parallellt med den utvecklingen utökades undervisningen med nya långa kurser och den allmänna kursen förändrades något. Läsåret 1970-1971 behölls den allmänna kursens två årskurser, men det gavs även en slöjd- och konsthantverkskurs. Dessutom gavs det året

39 Lennart Wallmark, Samernas folkhögskola: Jokkmokk: redogörelse för läsåret 1968-1969 (Jokkmokk: Svenska missionssällskapet, 1970), 18. Korhonen kom sedermera att bli professor i samiska språkstudier vid Umeå universitet

40 Exempelvis undervisade Nikolaus Kuhmunen, Nils Nilsson och Nils-Erik Spiik i nord-, syd- respektive lulesamiska under äsåret 1965-1966. Lennart Wallmark, Samernas folkhögskola: Jokkmokk: redogörelse för läsåret 1965-1966 (Jokkmokk: Svenska missionssällskapet, 1966), 6.

41 Wallmark (1966), 19; Wallmark (1969), 6-7; Wallmark (1970), 6-7. Läsåret 1968-1969 var eleverna indelade i två grupper där Wallmark och Olavi Kohronen undervisade nybörjarna en veckotimme och Nils-Eric Spiik hade en veckotimme med de elever som kunde mer. 1969-1970 angavs endast Olavi Korhonen som lärare i samiska.

42 Wallmark (1969), 7; Wallmark (1970), 8. 
en språkkurs i samiska på 20 poäng och 138 undervisningstimmar. ${ }^{43}$ Förutom den allmänna linjen Erbjöds i mitten av 1970-talet även sameslöjdslinjen, ekologilinjen och Sami Ällin (ungefär Samiskt liv). Slöjdlinjen var en specialiserad slöjdutbildning med få inslag av allmänna teoretiska skolämnen förutom samiska språk och annan samisk kultur. ${ }^{44}$ Slöjden hade alltid varit en viktig del av undervisningen på SF, men ekologilinjen var något nytt. Att ekologilinjen startades berodde på ett ökat samhälleligt intresse för miljöfrågor och ett uppmärksammande av de ingrepp som skedde i de områden som nyttjades för renskötsel. ${ }^{45}$ Till skillnad från de utbildningar som tidigare gavs vid SF krävde ekologilinjen att eleven tidigare läst endera på gymnasieskola eller folkhögskola. De studenter som utbildningen var avsedd för var inte nödvändigtvis samer utan de som såg universitetsstudier eller ett yrke inom turism eller naturvård framför sig. Ekologilinjen hade dock inslag om samisk kultur, med hänvisning till att även människan är en del av det ekologiska systemet i norr. Den tredje nya linjen, Sami Ällin, var en utbildning i samisk kultur och samhälle, ämnad för samer. Då linjen planerades såg det ut som att den skulle ges i tre varianter, men i praktiken gavs den som en linje där eleverna kunde göra individuella val. Även för Sami Ällin fanns vissa förkunskapskrav och eleverna förväntades ha goda praktiska och teoretiska kunskaper i något samiskt språk.

Sami Ällin gavs bara under ett par år under andra halvan av 1970-talet och få elever gick linjen. Slöjdlinjen intresserade däremot många elever, något som håller i sig än i dag. ${ }^{46}$ Grunden för slöjdlinjen var en utbildning i samisk slöjd, endera i mjuka material som textilier eller i hårda material som horn eller trä medan Sami Ällin istället hade immateriella delen av den samiska kulturen i centrum, exempelvis samiska språk. En annan skillnad var att slöjdlinjen i princip var det enda sättet att i Sverige förkovra sig i samisk slöjd för att sedan kanske ha det som yrke. För den som ville ha samiska språk, eller annan samisk kultur som del i ett framtida yrke fanns även andra vägar, något som kan ha påverkat Sami Ällins popularitet. Under åren 1977-1981 hade SF årligen mellan 60 och 77 elever, totalt 276 stycken. De allra flesta läste den allmänna linjen eller slöjdlinjen under den perioden, 106 respektive 82 elever. Sami Ällin hade endast 23 elever under de två läsår den gavs 1977-1979. ${ }^{47}$ Anledningen till att Sami Ällin-linjen upphörde kan ha berott på elevantalet men också på den konflikt som berörde SF under åren 1978 och 1979. Konflikten skildras längre fram i texten. Den allmänna linjen, med svensk kurslitteratur och huvudsakligen svenskspråkiga elever, lockade många elever under 1970-talet och dessutom var

43 Redogörelse år 1970-1971, F5, Samernas folkhögskola - Svenska missionssällskapet, Ajtte. Kursen om 138 timmar var ingen vanlig folkhögskolekurs utan en utlokaliserad universitetskurs. Av källorna att döma gavs den kursen bara en gång.

44 Samiskan hade fyra veckotimmar. Bilaga till styrelsesammanträde 15 maj 1976: Lärarnas tjänstgöring arbetsåret 1976/1977, E1:2, Samernas folkhögskola, Ajtte.

45 Intervju, Birgitta Östlund, 150421.

46 Slöjdlinjen var unik, men idag finns liknande utbildningar, till exempel inom ramen för linjen Design og håndverk i den norska motsvarigheten till Sveriges gymnasieskola. Design og handverk, http://design-handverk.no/.

47 Protokoll Samernas folkhögskolas skolstyrelse 9 september 1978, A1:1, Samernas folkhögskola, Ajtte; Elever till läsåret 78/79, F7C:2, Samernas folkhögskola, Ajtte; Verksamhetsåret 1979/80, F7C:2, Samernas folkhögskola, Ajtte; Registrering av anmälningar till kurser, F7C:2, Samernas folkhögskola, Ajtte. 
den linjen en förutsättning för statsbidragen. ${ }^{48}$ Därför var skolans verksamhet i stora stycken uppbyggd kring den allmänna linjen vars undervisningsinnehåll reglerades av staten. Tillsammans med de statliga kraven på lärarnas utbildning för anställning på en lärartjänst medförde detta att undervisningen på SF i huvudsak bedrevs av lärare som inte hade samiska som modersmål, och därmed undervisade på svenska. För de allra flesta eleverna var detta inget problem eftersom de var kunniga i svenska eller ett annat nordiskt språk, men för ett för ett fåtal samiska elever som sökt sig till skolan från Norge utgjorde språket ett hinder. ${ }^{49}$

Språkundervisningen vid SF under 1970-talet skiljde sig i viss mån från de tidigare årtiondenas genom att lärarledd undervisning var norm, och läraren mer ofta var anställd under längre tid. Det fanns också större möjligheter till mer avancerade studier, en konsekvens av att elevantalet ökade något. Dessutom ökade den språkliga kompetensen hos lärarna eftersom allt fler med samisk bakgrund anställdes. Det skedde däremot inga dramatiska förändringar gällande arbetssätt och läromedel. Ofta handlade det om katederundervisning, lärande av glosor, grundläggande grammatik, samt tal- och skrivövningar. Läromedlen var precis som tidigare för det mesta lärarens egenproducerade skrifter som kompletterades med annat material, exempelvis delar ur Israel Ruongs Samerna i historien och nutiden, tidningen Samefolket eller Nils Jernslettens Samisk elementorkurs: Tekster og glossar..$^{50}$ Med stiftelsen som huvudman och Birgitta Östlund som rektor ökade alltså andelen samer bland personalen och gradvis fick samisk tematik ett större utrymme i SF:s undervisning. Östlund förefaller inte ha varit ifrågasatt som rektor av de samiska lärarna, men då möjligheten kom lämnade hon över sin tjänst till läraren Ingwar Åhrén. I och med det fick SF sin förste samiske rektor år $1976 .{ }^{51}$

Undervisningen i samiska varierade allt mindre mellan åren av den orsaken att lärarna fanns kvar under längre tid. Eftersom lärarna själva behärskade samiska språk var kvaliteten högre än tidigare. Det fanns dock fortfarande de som var kritiska till de samiska språkens ställning på SF vilket åskådliggjordes då elevrådet förde fram sina åsikter vid ett styrelsemöte i februari 1977. Kritiken gällde punkter som behov av tolkning av undervisning i allmänna teoretiska ämnen, ökad differentiering av den samiska undervisningen på grund av elevernas varierade förkunskaper samt inställd undervisning i sydsamiska. ${ }^{52}$

48 De flesta eleverna till SF:s allmänna linje kom enligt en undersökning genomförd av skolan från många olika platser, men främst från Jokkmokks kommun eller övriga Norrbottens län. Förutsättningar för godkännande av kurs 001, E5:183, SÖ, RA.

49 Undervisningsspråket angavs aldrig uttryckligen i undervisningsjournalerna. Det språk som användes $i$ undervisning av allmänna skolämnen var svenska, medan samiskan antas ha använts i undervisning av samiska språk samt samisk slöjd. I undervisningsjournalerna användes inte samiskan annat än undantagsvis. Exempelvis används svenska för att beskriva slöjd med trä och horninriktning under läsåret 1972-1973 med P-O Utsi som lärare, precis som i beskrivningen av kursen Psykologi 1B med Anders Hultman som undervisande lärare. Undervisningsjournal 1972-1973 Slöjd: trä- och horninriktning, F7A:1, Samernas folkhögskola, Ajtte; Undervisningsjournal 1972-1973 Psykologi 1B, F7A:1, Samernas folkhögskola, Ajtte.

50 Enligt Ingwar Åhrén som undervisade och även var rektor under ett antal år under 1970-talet kunde inte det material som användes under SMS-tiden användas. Lärarna skapade i stället sitt eget material. Intervju, Ingwar Åhrén, 13 april 2015.

51 Intervju, Birgitta Östlund, 21 april 2015; Samernas utbildningscentrum (2013), 25; Birgitta Östlund, "På en minnepinne," "Samernas" 70 år i samernas tjänst: Jubileumstidning (Jokkmokk: Sámij åhpadusguovdasj, 2013), 19.

52 Protokoll styrelsen för samernas folkhögskola 8 februari 1977, A1:2, Samernas folkhögskola, Ajtte. 
Styrelsen bemötte kritiken genom argument grundade i de ekonomiska förutsättningarna. Medel till tolktjänst saknades helt och redan med den uppdelning som då var fallet var språkundervisningen underfinansierad på grund av för litet elevantal. ${ }^{53}$ Gällande den sydsamiska undervisningen så förhöll det sig så att den tilltänkte läraren var tjänstledig och en ersättare hade inte kunnat anställas. Dessutom saknades läromedel för den språkundervisningen. Styrelsen hade dock förståelse för elevernas önskemål och de förslag till åtgärder som diskuterades lämnades över till arbetsutskottet. Förslagen handlade om att försöka locka fler studenter till SF från grannländerna, att använda skolans bibliotekarie för att översätta information till samiska och dessutom önskades en tolkkurs. ${ }^{54}$ I maj samma år dryftades språkproblemen igen. Då fattades beslut om att konstruera en tjänst där tolkning liksom undervisning i samiska kunde ingå, något som blivit möjligt tack vare en förändring i villkoren för hur statsbidragen kunde användas. ${ }^{55}$ Resultatet av detta var att styrelsemötet 28 september 1977 beslöt att anställa Elli Sivi Näkkäläjärvi på en 75 \% tjänst som lärare, och som ansvarig för skolans tolkverksamhet. ${ }^{56}$ Hennes arbete som lärare och tolk syns dock i undervisningsjournalerna först i samband med läsåret 1978-1979. Näkkäläjärvi avvek från normen då hon i undervisningsjournalerna beskrev många av de skolämnen hon undervisade i på samiska och inte på svenska. ${ }^{57}$ Hennes engagemang för samiskan visade sig även i samband med språkbojkotten.

Med hänvisning till språkfrågan inkom en skrivelse till SF den 20 oktober 1978 och det blev starten på den enda större konflikt som framträder i källmaterialet under den undersökta perioden. I skrivelsen förklaras att ett antal akademiskt utbildade samer i Sverige bojkottar skolan. De ville inte bidra till tolkning eller undervisning på skolan eftersom det anställts två personer utan goda kunskaper i samiska: ett ekonomibiträde och en bildningskonsulent..$^{58}$ Detta ansågs vara ett avsteg ifrån de principer som SSR och Same Ätnam hade: att bevara och utveckla samisk kultur och att de som arbetade vid samiska institutioner skulle behärska ett samiskt språk. ${ }^{59}$ Bland de bojkottande fanns lärare vid skolan och andra samer. Den nyligen anställda Näkkäläjärvi framstår som en av de mer engagerade i bojkotten. Hon lämnade in en avskedsansökan i samband med att bojkottskrivelsen nådde $\mathrm{SF}^{60}$

Näkkäläjärvi anger särskilt tillsättningen av bildningskonsulenten som anledning till vilja säga upp sig. Tjänsten ansågs ha tillsats utan att hon som medlem av lärarrådet haft möjlighet att yttra sig. Den anställda konsulenten, Elisabeth Andersson, lämnade också in en avskedsansökan, diarieförd 11 oktober 1978, alltså före bojkott-

53 Exempelvis hade kurserna i nybörjarsamiska och sydsamiska enligt undervisningsjournalerna bara tre respektive sex elever vardera under 1977-1978. Undervisningsjournal nybörjarsamiska 19771978, F7A:2, Samernas folkhögskola, Ajtte; Undervisningsjournal sydsamiska 1977-1978, F7A:2, Samernas folkhögskola, Ajtte.

54 Protokoll styrelsen för samernas folkhögskola 8 februari 1977, A1:2, Samernas folkhögskola, Ajtte.

55 Protokoll styrelsen för samernas folkhögskola 23 maj 1977, A1:2, Samernas folkhögskola, Ajtte.

56 Protokoll styrelsemöte 28 september 1977, A1:1, Samernas folkhögskola, Ajtte.

57 Undervisningsjournaler 1978-1979, F7A:2, Samernas folkhögskola, Ajtte.

58 Från och med 1958 fanns möjlighet att kombinera en tjänst som folkhögskollärare och regional bildningskonsulent. SOU 1976:16, 55.

59 Skrivelse dnr 2577, E1:12, Samernas folkhögskola, Ajtte.

60 Skrivelsen och avskedsansökan bär samma diarienummer och båda handlingarna är stämplade med samma datum, dnr 2577, 20 oktober 1978. I sin uppsägning hänvisar Näkkäläjärvi till den "bifogade skrivelse[n] "Språkbojkott av Samernas Folkhögskola". 
skrivelsen nådde styrelsen. ${ }^{61}$ För rektor Ingwar Åhrén blev situationen komplicerad i och med att bildningskonsulenten sagt upp sig. Det stora problemet var dock Näkkäläjärvis beslut att säga upp sig - hon hade en stor del av sin undervisning i de teoretiska samiska ämnena. I slutet av oktober inleddes en intensiv tid på SF där de samiska språken stod i centrum. De som undertecknat skrivelsen 28 oktober kontaktades av skolans styrelses arbetsutskott i ett försök att lösa situationen. Arbetsutskottet förklarade bland annat att konsulenten hade erfarenheter från samiska organisationer, något som var viktigt då hon fick tjänsten. Vidare konstaterades att det fanns tolv personer med kunskaper i nord-, lule-, och sydsamiska vid skolan vilket ansågs täcka behovet av samiskspråkig personal. Arbetsutskottet menade också att arbetet för samiskan skadades av bojkotten. ${ }^{62}$

Efter bojkottskrivelsen inkom andra skrivelser i ärendet. Merparten höll i sak med de som initierat bojkotten, men det inkom även skrivelser med andra åsikter. Exempelvis meddelade två av undertecknarna att de avbröt sin bojkott med anledning av att de informerats om att de som fătt tjänsterna var samer, och inte som de trodde, icke-samer. De menade också att det var fel att införa en bojkott utan att först ha använt bojkotten som ett verktyg i förhandlingar. Vidare skrevs att bojkottskrivelsen använts "för ett syfte som ej framgick i texten. Nämligen att alla tjänster ska tillsättas med nordsamiskttalande samer och därigenom få till följd att sydsamerna blir helt utestängda från folkhögskolans tjänster.” ${ }^{63}$ Även SF:s elever författade en resolution med anledning av språksituationen och även de ansåg att samiska skulle vara ett viktigt kriterium för anställning vid skolan, men de var inte lika dramatiska som författarna till bojkottskrivelsen. ${ }^{64}$ Bland de som undertecknade bojkottskrivelsen bildades en kontaktgrupp och bland dem fanns Näkkäläjärvi tillsammans med Ellen Burman, Kåre Urhem, samt suppleanterna Per Mikael Utsi, Lars H:son Simma och Sigrid Stångberg. ${ }^{65}$ Diskussioner fördes mellan skolledningen och kontaktgruppen men situationen förändrades inte. Framförallt blev avsaknaden av språklärare påtaglig.

Rektor Åhrén försökte anställa en ny språklärare men lyckades inte, något som innebar att elevernas studier fick arrangeras på annat sätt inför vårterminsstarten 1979. Linjen Sami Ällin var till stor del uppbyggd kring samisk kultur och samiska språk, och eftersom det saknades lärare i exempelvis nordsamiska fick eleverna, om de så ville i stället gå någon av de andra linjerna på skolan. ${ }^{66}$ Då så var möjligt kompletterades dessa studier med andra studier i samiska. Vårterminen 1979 innebar fortsatta turer kring tjänsterna på SF. Elisabeth Andersson, den konsulent som sade upp sig strax före bojkotten inleddes återtog sin avskedsansökan i början av

61 Skrivelse dnr 2598, E1:12, Samernas folkhögskola, Ajtte.

62 Bilaga 5, Protokoll styrelsen 7 november 1978, A1:2, Samernas folkhögskola, Ajtte.

63 Skrivelse dnr 2589, E1:12, Samernas folkhögskola, Ajtte.

64 Protokoll styrelsen 7 november 1978, A1:3, Samernas folkhögskola, Ajtte; Bilaga till styrelseprotokoll 7 november 1978, A1:3, Samernas folkhögskola, Ajtte.

65 Meddelandet till SF:s ledning om att kontaktgruppen bildats och vilka dess medlemmar var är diariefört 22 november 1978. Detta följdes av en skrivelse från Stångberg diarieförd 27 november 1978 där hon meddelar att hon inte längre deltar i bojkotten. Skrivelse dnr 2610, E1:12, Samernas folkhögskola, Ajtte; Skrivelse dnr 2614, E1:12, Samernas folkhögskola, Ajtte.

66 Skrivelse dnr 2634, E1:12; Samernas folkhögskola, Ajtte; Skrivelse dnr 2630, E1:12, Samernas folkhögskola, Ajtte. 
november, men sade upp sig igen en tid därefter. ${ }^{67}$ Redan tidigare hade delar av de bojkottande försökt påverka situationen genom att vända sig till Skolöverstyrelsen (SÖ). Mariana Blind, en av de sökande till bildningskonsulenttjänsten, överklagade hos SÖ och menade då att SF:s styrelse frångick de principer för samiska språk som satts upp av de styrande organisationerna, SSR och Same Ätnam, samt att det var fel att anställa en bildningskonsulent utan kunskaper i samiska med anledning av att en del av arbetsuppgifterna var att ordna vuxenutbildning för samer. Blinds klagomål skickades till SÖ före bojkottskrivelsen nådde SF. Även en studerande klagade hos SÖ och han ville få utrett om SF hade rätt att i praktiken plocka bort Sami Ällin-utbildningen för att ersätta den med en annan utbildning. ${ }^{68}$ SÖ svarade studenten att SF:s styrelse gjort det som varit möjligt för att eleverna ska lida så lite som möjligt av situationen. ${ }^{69}$ SÖ valde alltså inte att kritisera SF vid detta tillfälle.

Inte heller Blinds överklagan renderade i någon åtgärd från SÖ:s sida, men i svaret förklarades att vare sig Blind eller Andersson var kvalificerade för tjänst som lärare på en folkhögskola. Därför uppstod en knepig situation då Blind sökte och fick den tjänst som Andersson lämnade - eftersom Blind inte var kvalificerad för tjänsten kunde hon bara få ett visstidsförordnande..$^{70}$ Blinds tillträde till bildningskonsulenttjänsten innebar dock att bojkotten avbröts. Bojkotten lade sig under 1979 och höstterminen 1980 fanns återigen personal med kompetens i tre samiska språk. Däremot gavs inte Sami Ällin-linjen. Kursen diskuterades i planeringen inför 1981 års höstterminsstart, men gavs inte som egen linje efter läsåret 1978-1979. Förutom förändring av kursutbudet kom också rektor Åhrén att lämna sin plats år 1980. ${ }^{71}$ Denna gång skedde ingen handplockning utan en offentlig utlysning. Efter många turer och flera överklaganden kunde till sist Per Mikael Utsi att utses till rektor år 1981, en post som han hade till $1990 .^{72}$

Under perioden 1972-1980 förändrades alltså sammansättningen av lärare på skolan så att ett ökande antal samer med kunskap i samiska var anställda vid skolan, något som medförde en högre grad av kontinuitet och en högre kvalitet på språkundervisningen. Under samma period uppstod en konflikt vid skolan som grundade sig i språkfrågan. Språkbojkotten synliggjorde också att det uppstått viss friktion mellan olika grupper av samer, samt mellan samer och andra etniska grupper. Grunden till situationen beskrivs inte i undersökningens material, och eftersom det inte i det övriga källmaterialet från SF framträder sådana stridigheter bör konflikten mellan samiska grupper inte överdrivas. Att språkfrågan var laddad och att det fanns en konflikt märks dock i skrivelser som inkom till SF med anledning av bojkotten. I själva bojkottskrivningen anklagas skolledningen och skolans styrelse till exempel för att inte ta hänsyn till språkkunskaper och samisk bakgrund. Dessutom beskrevs

67 Protokoll Samernas folkhögskolas skolstyrelse 7 mars 1979, A1:1, Samernas folkhögskola, Ajtte.

68 Skrivelse dnr. 2569, E1:12, Samernas folkhögskola, Ajtte; Skrivelse dnr 2692, E1:12, Samernas folkhögskola, Ajtte.

69 Skrivelse dnr 2827, E1:14, Samernas folkhögskola, Ajtte.

70 Skrivelse dnr 2776, E1:12, Samernas folkhögskola, Ajtte.

71 Intervju, Ingwar Åhrén, 13 april 2015.

72 Sammanträdesprotokoll arbetsutskottet 22 augusti 1980, A1:7, Samernas folkhögskola, Ajtte; Bilaga 2 till sammanträdesprotokoll arbetsutskottet 25 februari 1981: Besvär till SÖ över beslut att förordna Per Mikael Utsi som rektor, A1:7, Samernas folkhögskola, Ajtte; Sammanträdesprotokoll arbetsutskottet 18 mars 1981, A1:7, Samernas folkhögskola, Ajtte; Samernas utbildningscentrum (2013), 25. 
dolda agendor hos de som författade bojkottskrivelsen i andra skrivelser. Att det bland samer som inte tillhörde den nordsamiska delen av den samiska befolkningen fanns en känsla av att vara förfördelade framträder i tidskriften Saminuorras juninummer 1979. Där intervjuas Elisabeth Andersson och Inez Fjällström, den bildningskonsulent respektive kamrer vars tillsättningar ifrågasattes av de bojkottande.

Andersson förklarar situationen med att den handlade om att samer tog efter det omgivande samhällets byråkrati samtidigt som de bekämpade den. En annan möjlighet fanns också: de samiska institutionerna hade ökat i antal och det saknades vana av att driva sådana. Det gav i sin tur upphov till misstro bland samer och särskilt mot de som arbetade på samiska institutioner. Även om Andersson gav de bojkottande delvis rätt i frågan om hennes bristfälliga språkliga kompetenser menade hon att det var fel att kamrerstjänsten också kom att inkluderas bland orsakerna till bojkotten. Kamreren Fjällström behärskade nämligen sydsamiska. Fjällström var mer kritisk till de bojkottande och ansåg att konflikten mellan nordsamer och andra grupper av samer förvärrats genom språkbojkotten. Dessutom hade bojkotten inte ökat möjligheterna att använda samiska på skolan. I stället har det blivit en "nonchalant syn på samiskan. Man känner att det tär på en personligen, angrepp på att man inte är lika fullvärdig same, som den som kan samiska!” Fjällström menade även att sydsamerna slutit sig mer samman för att finna trygghet inom den egna gruppen, samt att det var fel att ha språk som grund för jämförelser mellan samer.

Artiklarna där intervjuerna ingår visar att det funnits en känsla av konflikt mellan olika grupper av samer, och att den mångtaligare gruppen genom påtryckningar förändrade personalsammansättningen på SF. Artikelförfattaren i Saminuorra driver i sin epilog tesen om att språkbojkotten handlade om tjänster och inget annat, samt att det är fel med språkkunskaper som kriterium eftersom det finns samer som inte fått chansen att lära sig samiska. ${ }^{73}$

\section{Samiska språk under perioden 1981-1990}

Trots språkbojkotten förefaller SF ha präglats av en positiv anda under 1970-talet där många lärare och elever samarbetade för förbättra skolan, undervisningen och övrig samisk verksamhet. Lite av kontroverser syns i källmaterialet från tiden, de är mer framträdande i dokumentationer som skapats senare. ${ }^{74}$ Sedan Per-Mikael Utsi installerats som rektor i början av 1980-talet tycks arbetet vid skolan framför allt ha präglats av stabilitet, så även undervisningen i de samiska språken.

Att Sami Ällin-kursen utgick innebar inte att möjligheter till studier av samiska språk och samisk kultur försvann. Liksom tidigare erbjöds längre kurser i samiska som framför allt studerades av elever på slöjdlinjen där språk och kultur var viktiga delar av lärostoffet. Även elever som läste den allmänna linjen kunde ta del av undervisning i samiska. Dessutom gavs kortare kurser i samiska. Kurserna i samiska hade trots den betydelse som språket tillmättes få elever i jämförelse med många andra kurser som gavs vid skolan. Läsåret 1981-1982 hade exempelvis en kurs med namnet Samisk kulturorientering 29 elever medan en kurs i Nordsamiska hade fem

\footnotetext{
73 "Språkstriden på Samernas folkhögskola", Sáminuorra, nr 1 (1979), 2, 15.

74 Exempelvis i Östlund (2013), 18.
} 
elever. ${ }^{75}$ Även om möjligheten fanns för alla elever på skolan att förkovra sig i samisk kultur och samiska språk var det alltså främst slöjdlinjens elever som gjorde det. Slöjdlinjen hade dessutom förhållandevis många elever, cirka 25 stycken årligen, och nästan utan undantag var alla samer. ${ }^{76}$

Intresset för slöjdlinjen höll i sig medan de övriga linjernas elevantal minskade under 1980-talet. Eftersom SF:s ekonomi var beroende av elevantalet och framför allt antalet elever på den allmänna linjen innebar nedgången problem. ${ }^{77}$ Skolledningen försökte genom exempelvis annonser och försök med basketprofil locka elever till SF. Trots dessa åtgärder tilltalades inte längre elever av den allmänna linjen och skolledningen ökade därför sina insatser för att få annan finansiering av skolans utbildningar. Problemen fick sin lösning 1990 då det beslutades på statlig nivå att SF inte längre behövde ha allmän linje för sin finansiering. I stället skulle ett särskilt statsbidrag utgå till skolan som fick användas "för sådan undervisning, som efter styrelsens bedömning bäst tjänar samernas sak" ${ }^{78}$ Den förändringen innebar att SF inte behövde uppfylla de tidigare kravet på allmän linje och som en konsekvens därav kom den allmänna linjen liksom ekologilinjen att sedermera försvinna från undervisningsutbudet.

Som tidigare nämnts var elevantalet ett konstant problem för skolan och kanske framför allt då det gällde undervisningen i de samiska språken. Ett annat bekymmer var att undervisningen varierade mellan åren, något som berodde på personalomsättningen samt de läromedel som användes i undervisningen av samiska språk. Nästan utan undantag skapade lärarna i samiska själv sitt undervisningsmaterial, om än kompletterat med läromedel och ordböcker som fanns att tillgå, och så hade det varit ända sedan 1940-talet. Under 1980-talet förändrades detta då det i ett nordiskt samarbete utvecklades ett läromedel för två olika kurser: nordsamiska för nybörjare, samt nordsamiska för elever med tidigare kunskaper. Detta läromedel, Davvin, utvecklades av Utbildningsradion (UR) och motsvarande institutioner i övriga nordiska länder tillsammans med samiska intressenter. Läromedlet omfattade texter, men också exempelvis radioprogram. Läromedlet var avsett för att kunna användas för studiecirklar men också för självstudier. I Sverige tillhandahöll SF utbildning för cirkelledare och under höstterminen 1983 igångsattes 13 studiecirklar i Norr- och

75 Undervisningsjournal nordsamiska 1981-1982, F7A:2, Samernas folkhögskola, Ajtte; Undervisningsjournal samisk kulturorientering 1981-1982, F7A:2, Samernas folkhögskola, Ajtte. Dessutom hade kursen i Nordsamiska aldrig alla elever på plats vid ett och samma tillfälle.

76 Antagningskraven för studier vid slöjdlinjen var formulerade så att den som genomgått sameskola eller kunde styrka motsvarande utbildning eller praktik hade tillträde. Det innebar att nästan bara den som själv var same hade tillträde till utbildningen. Ekologilinjen krävde tidigare studier, åtminstone 2 år på folkhögskola, medan den allmänna linjen var öppen för alla som fyllt 18 år. Broschyr, bilaga till styrelsemöte 9 juni 1983, A1:7, Protokoll Samernas folkhögskolas styrelses möten, Ajtte.

77 Betydande intäkter kom via uthyrning av rum på elevhemmet. Statsbidrag gavs framför allt för elever på den allmänna linjen vilket gjorde att då de uteblev så blev ekonomin kärvare. Intervju, Per-Mikael Utsi, 15 maj 2015.

78 Proposition 1990/91:82, Om folkbildning, https://www.riksdagen.se/sv/Dokument-Lagar/Forslag/Propositioner-och-skrivelser/om-folkbildning_GE0382/?html=true; Riksdagens protokoll 1990/91:129, https://www.riksdagen.se/sv/Dokument-Lagar/Kammaren/Protokoll/_GE09129/; Historik Samernas folkhögskola/utbildningscentrum, http://www.samernas.se/om-samernas/historik/ . Citatet från utbildningsutskottets betänkande, 1990/91:UbU18, https://www.riksdagen.se/ sv/Dokument-Lagar/Utskottens-dokument/Betankanden/Folkbildningen_GE01UbU18/; Intervju Per-Mikael Utsi, 5 maj 2015. 
Västerbotten. Vidare kom en person ur SF:s personal att ingå i ledningsgruppen för läromedlet och skolan utgjorde även mötesplats för några av ledningsgruppens möten. Davvin kom att användas i SF:s egen språkundervisning för elever i nordsamiska på olika nivåer. ${ }^{79}$ Läromedlet var ämnat för nordsamiska, men eftersom SF:s lärare ibland undervisade elever med olika språklig bakgrund var läromedlet till viss hjälp även i undervisningen i andra språkvariteter. Med Davvin kom undervisningen i samiska att bli mer som "vanlig" undervisning i språk, något som framgår av undervisningsjournalerna. Liksom i exempelvis engelska kom eleverna att följa läromedlet, läsa dess texter, lösa dess uppgifter, lyssna på uppläsningar samt få instruktioner och förklaringar av en lärare. Även de andra samiska språken fick ett liknande upplägg, men eftersom ett motsvarande läromedel saknades var det fortfarande upp till läraren att sätta samman läromedlen. ${ }^{80}$

Davvin-läromedlet bidrog av allt att döma till att undervisningen i samiska inte varierade lika mycket över tid eller mellan lärarna. Framför allt i Nordsamiska ökade alltså kvaliteten under 1980-talet, men samtidigt kvarstod dilemmat att eleverna var fortsatt få, att de hade varierande språkkunskaper samt olika samiska språktillhörigheter. Dessutom var det svårt att förutse vilka samiska språk som eleverna ville förkovra sig i före höstterminens början. För att minska konsekvenserna av att eleverna var få erhölls extra ekonomiskt stöd från staten, men trots lärarnas kompetens kunde inte elevernas vilja att lära sig "sin samiska" alltid tillgodoses. Exempelvis skriver Mariana Blind i undervisningsjournalen för Samiska-rennäringslinjen 1988-1989 att "då kursens 4 deltagare hade så olika förkunskaper i samiska att därtill fanns i gruppen tre samiska huvuddialekter var det svårt att få en gemensam grupp av dem. Därför blev inte undervisningen vad jag hade tänkt mig och kanske inte heller vad eleverna tänkt sig. De hade helst velat ha undervisning i just sin egen dialekt." ${ }^{81}$ Sådana personliga kommentarer är ovanliga journalerna vilket gör det troligt att Blind ansåg att situationen verkligen var bekymmersam. Situationen för lärare och elever på kurserna i samiska förbättrades alltså tack vare Davvin-läromedlet. Tack vare det materialet samt ökande kompetens hos lärarna och det faktum att lärarna fanns kvar allt längre vid skolan blev undervisningen i samiska allt stabilare. Samtidigt kvarstod delar av de bekymmer som fanns redan då SF startade: elevernas varierande bakgrund och skiftande språkkunskaper, samt deras antal. Kontinuitet snarare än förändring kännetecknade alltså SF fram till undersökningsperiodens slut år 1990.

\section{Diskussion}

Verksamheten på SF påverkades i högsta grad av statens regler för folkhögskolors medelstilldelning, men vad det gäller språkundervisningen är frågan om inte statens hållning gentemot Sveriges samer i andra frågor var av ännu större betydel-

79 Så skedde exempelvis i 1987-1988 samt 1988-1989. Undervisningsjournal Samiska - nord, grupp B, 1987-1988, F7A:4, Samernas folkhögskola, Ajtte; Undervisningsjournal Samiska-profil, grupp allmän, 1988-1989, F7A:4, Samernas folkhögskola, Ajtte; Undervisningsjournal Samiska - B, grupp slöjd, 1988-1989, F7A:4, Samernas folkhögskola, Ajtte.

80 Se exempelvis Undervisningsjournal Samiska - nord, grupp B, 1987-1988, F7A:4, Samernas folkhögskola, Ajtte; Undervisningsjournal Samiska - Allmän linje samisk profil, 1988-1989, F7A:4, Samernas folkhögskola, Ajtte; Undervisningsjournal Samiska - rennäringslinjen, 1988-1989, F7A:4, Samernas folkhögskola, Ajtte; Undervisningsjournal Lulesamiska, Vårterminen 1991, F7A:4, Samernas folkhögskola, Ajtte.

81 Undervisningsjournal Samiska - rennäringslinjen 1988-1989, F7A:4, Samernas folkhögskola, Ajtte. 
se. Genom de lagar och regler som kringgärdade rennäringen och nomadskolans införande kom samer att segregeras. De blev de av Said beskrivna "andra", om de inte redan var det. Dessa politiska beslut kom även att innebära att det samiska folket delades upp och skillnaderna mellan olika grupper ökade. Det metasystem som Elenius menar fanns i norr kom att påverka samerna i hög grad. Samiska barn placerades i folk- eller nomadskola beroende på deras föräldrars näringsfång. Liksom de finskspråkiga barnen i norra Sverige fick många samiska barn inte tillgång till sitt eget språk. Dessutom hade nomadskolans elever en mindre omfattande utbildning än folkskolans elever, vilket gjorde dem mindre förberedda för de förändringar som skedde i 1900-talets Sverige. SMS, med erfarenhet av att verka bland samer såg en möjlighet att inte bara öka unga samers möjlighet till medborgerlig bildning, chanser till högre utbildning eller ett arbete utanför de traditionella näringarna utan även att hjälpa samerna att bevara och utveckla sitt språk och sin kultur. Av dessa orsaker startades SF år 1942 och liksom i den norska föregångaren erbjöds undervisning på samiska. Men, medan SMS lämnade sin folkhögskola under det tidiga 1970-talet behöll Norsk Finnemisjon sin skola tills den till sist lades ned under 1980-talet. Under hela undersökningsperioden undervisades det i samiska språk på SF, men undervisningen liksom dess förutsättningar varierade.

Under perioden 1942-1990 studerades flera språk på SF, däribland samiska. Under de första decennierna tilldelades dock samiska språk mindre undervisningstid än exempelvis svenska eller engelska, en konsekvens av att undervisningen var tvungen att följa den allmänna kursens innehåll. Denna kurs eller linje som den sedermera kallades var obligatorisk för de folkhögskolor som önskade statliga medel till sin verksamhet. Den allmänna kursen skulle innehålla "allmänna skolämnen", exempelvis matematik eller svenska, men det fanns möjligheter till tillägg och undervisning i samiska var ett sådant. Då stiftelsen tog över huvudmannaskapet i början av 1970-talet, utökades också utbudet av längre kurser, däribland kurser med samiskt tema. Förändringarna medförde att samisk tematik kom att få större utrymme vid skolan samt att fler elever lockades till skolan, något som i sin tur innebar en gynnsammare ekonomisk situation. När elevantalet åter kom att vika under 1980-talets slut inleddes ett arbete för att staten skulle undanta SF från kravet på att erbjuda allmän linje. Ansträngningarna gav resultat år 1990, och från och med hösten 1991 behövde den allmänna kursen inte längre ges. Samiska teman kom därefter att helt dominera SF:s utbildningar.

Inte under någon del av undersökningsperioden kan SF sägas ha haft samma roll i ett metasystem för försvenskande likt folkhögskolorna som vände sig till Tornedalens ungdomar. ${ }^{82}$ SF skulle som tidigare nämnts ge unga samer chansen att lära sig eller behålla sitt språk. En möjlig orsak till denna skillnad står att finna i att nationalismen som idéströmning hade tappat i kraft då SF startade. En annan möjlig faktor kan vara inspiration från den folkhögskola för samer som startades några år tidigare i Norge, där undervisning i samiska erbjöds. Vare sig skolan i Norge, eller någon förändrad diskurs kring nationalism framträder dock i källmaterialet. Däremot är SMS egen historia som spridare av det kristna ordet samt undervisare bland samer mycket tydlig. SMS hade tidigare goda möjligheter att verka bland samer genom sina missionsskolor, men blev marginaliserade i det metasystem som omfattade männ-

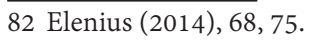


iskorna i norr. Den statliga folkskolan och nomadskolan ersatte kristendom med nationalism samtidigt som statens monopol över samiska barns skolgång etablerades. Med en egen folkhögskola fick SMS möjligheten att åter bidra till samers utbildning utan att göra avkall på missionstanken. Dessutom fanns inom SMS en uppfattning om att det samiska folket höll på att utarmas, inte minst kulturellt. De samiska språken ansågs vara centrala för den samiska kulturen, och därför arbetade SMS för att erbjuda undervisning i samiska. Denna strävan förefaller inte ha varit något utslag av önskan att hålla samer kvar som ett slags exotisk kvarleva från förr. I stället var bevarandet av kultur och språk, en del i en idé om utveckling där målet var att samerna själva skulle ha möjligheter, vilja och förmåga att påverka sin egen framtid. Även SMS engagemang för skapandet av samiska organisationer för kultur och näringsliv får sägas vara ett uttryck för denna tanke.

När SMS lämnade skolan och stiftelsen tog över huvudmannaskapet utökades undervisningsutbudet med fler långa kurser. De samiska språkens utrymme i de långa kursernas veckoscheman blev inte särskilt mycket större, men succesivt kom samiska att användas allt mer på SF. Detta var en konsekvens av att fler samer som talade samiska kom att finnas bland skolans personal och elever. Ett problem under SMStiden var personalomsättningen, bland annat byttes lärarna i samiska ofta ut, och ibland löstes undervisningen med att personer som inte själva kunde något samiskt språk höll i en studiecirkel i samiska. Under 1970-talet stannade lärarna något längre vid skolan än vad som tidigare varit fallet. Den stora skillnaden var däremot att de som undervisade i samiska språk själva var samer och kunniga i språket. Emellertid var de inte alla gånger formellt utbildade lärare. Tack vare att lärarna var kunnigare och att de stannade något längre vid skolan blev skillnaderna mellan åren allt mindre. Det stora problemet med språkundervisningen under SMS-tiden var dock inte läraromsättningen, utan att skolan hade alltför få elever, något som förändrades under 1970-talet då elevantalet ökade.

Bland de elever som under 1970-talet sökte sig till SF var många svenskar men det kom även elever från andra länder. Den samiska delen av elevgruppen ökade jämfört med det sena 1960-talet. Det ökade elevantalet minskade de ekonomiska bekymren något, men språkundervisningens andra dilemma försvann inte: de många samiska språkvariteterna, och elevernas önskan att få studera "sitt" samiska språk. Dessutom varierade elevernas kunskaper i samiska liksom tidigare. Variationer mellan elevgruppernas sammansättning innebar fortsatta olikheter i undervisningen, men mindre än tidigare. Framför allt var undervisningen i nordsamiska tämligen konstant, och det läromedel som introducerades under 1980-talet bidrog i hög grad till det.

Före läromedlet Davvin var det upp till läraren att sammanställa texter, uppgifter och annat undervisningsmaterial. Det berodde på att det inte fanns läromedel i samiska på folkhögskolenivå. Med undantag av universiteten var SF det enda ställe i Sverige där samiska språk kunde studeras. Efter 1950-talets slut blev samiska tillgängligt i nomadskolan, senare sameskolan, men den skolformen var ämnad för barn. Därför fick SF:s lärare fortsätta att själva sammanställa övningar, ta fram lämpliga texter med mera att använda i undervisningen. Därmed hade lärarna i samiska ett mer tidskrävande arbete än de som undervisade i ett språk som engelska där färdiga läromedel fanns tillgängliga. Då Davvin-läromedlet kom, blev det använt i stor omfattning i den nordsamiska undervisningen, och det influerade även undervisning i de samiska språkvariteter där det saknades ett modernt läromedel. Genom 
Davvin kom samiskan att likna undervisningen i andra språk, med ett läromedel som följdes noggrant. Läromedlet förenklade lärarnas arbete, men fortfarande hade SF få elever i varje språkvaritet, och de hade även fortsättningsvis varierande förkunskaper. De ekonomiska konsekvenserna av att ha små undervisningsgrupper minskades något av SF:s dispenser gällande undervisningsgruppernas storlek, men elevernas lärande underlättades inte.

För att sammanfatta språkundervisningens förändringar under perioden 19421990 så var den inledningsvis främst påverkad av vilka elever som sökt sig till SF och de lärare som fanns vid skolan ett aktuellt år. Detta var en konsekvens av de krav staten ställde på den som ville ha en lärartjänst samt på statens system för ekonomiskt stöd. Givetvis påverkades situationen också av de beslut som skapat en situation där samer i varierande grad kunde behärska sitt eget språk och dessutom, likt många andra ungdomar i Sverige ansåg sig behöva studier på folkhögskola för att förbättra sina möjligheter i samhället. Under undersökningsperiodens sista årtionden hade fler samer fått högre utbildning och de kunde därför tillsvidareanställas vid SF, en konsekvens av de förändringar i utbildningssystemet som skedde i riket efter 1945. Lärarnas språkliga kompetens och deras formella utbildning bidrog till att undervisningen i samiska kom att likna den i andra språk. Samtidigt fanns några av de gamla problemen kvar: få utövare av vissa samiska språk och varierande förkunskaper hos eleverna.

Den undervisning i samiska som bedrevs på SF kan inte betraktas som vilken språkundervisning som helst. Framför allt var SF en betydelsefull institution under de första åren, då samiska, liksom finska, inte tilläts i folk- eller nomadskolornas klassrum. På SF var samtal på samiska istället uppmuntrat och dessutom undervisades det i samiska. SMS syfte med SF var inte bara att utbilda samer utan även att stärka samernas självkänsla så att de i högre grad ville, och kunde arbeta för det egna folkets kultur. Den ambitionen till trots lämnade SMS ifrån sig SF till en stiftelse. Förmodligen skedde det vid rätt tid - Norsk Finnemisjon höll fast vid sin folkhögskola betydligt längre, men tvingades lägga ned den i mitten av 1980-talet. Den stora skillnaden är att SMS lämnade sitt huvudmannaskap då den samiska aktivismen tog fart på allvar under 1970-talet. I och med det kunde det samiska folket på ett annat sätt påverka sin folkhögskola, vilket gjorde den fortsatt relevant. Men, i och med att SF kom att ha samer i ledningen och en ökande andel samer i personalen, blev också diskussionen om det samiska annorlunda. Då Wallmark var rektor tycks det ha varit hans uppfattning om vad som var samisk kultur som avgjorde vad som fick utrymme i SF:s verksamhet. När stiftelsen tog över var det inte längre lika definitivt vilken samisk kultur som skulle finnas vid skolan. Därmed tycks något av en förhandling kring samiskhet ha pågått vid skolan, något som kom till ytan i samband med språkbojkotten 1978.

Språkbojkotten och konflikten mellan olika grupper av samer är inte framträdande i de handlingar som upprättades vid skolan, och därför ska dess betydelse inte överdrivas. Förvisso fanns praktiska problem bland orsakerna till bojkottaktionen, men de hade funnits även tidigare. Konflikten, eller kanske snarare förhandlingen, gällde samiskhet snarare än tolkhjälp. I samband med språkbojkotten utövade samer påtryckningar på andra samer och språket var centralt i diskussionerna. Bojkottaktionen gjorde det tydligt att språkkunskaper var en viktig faktor för en persons 
position på den kulturstege som Åhrén beskriver. ${ }^{83}$ Den med samisk identitet som besatt kunskaper i samiska stod på en högre nivå än den utan sådana kunskaper. Det förefaller också som att de med sydsamisk tillhörighet ansåg sig ha sämre framgångar under förhandlingarna än nordsamerna. Ett av aktionens resultat var att en person som inte behärskade samiska lämnade sin tjänst och att en nordsamisktalande person i stället fick tjänsten. I språkbojkottens efterdyningar lämnade rektor Ingwar Åhrén skolan och Per-Mikael Utsi tillträdde år 1981. Därefter syns inte i källmaterialet någon konflikt mellan samer av olika bakgrund, och inte heller framträder någon diskussion gällande språk, eller språkundervisning utöver praktiska spörsmål gällande undervisningen. Början på 1980-talet verkar ha inneburit att den förhandling om kulturstegen som fanns under 1970-talet var över, och att det avgjorts vad som skulle ha lägre eller högre status, åtminstone vid SF.

83 Åhrén (2008), s. $183-85$. 


\section{Referenser \\ Arkiv \\ Ájtte, Svenskt fjäll- och samemuseum (Ajtte) \\ Samernas folkhögskola - Svenska missionssällskapet \\ Redogörelse år 1970-1971, F5.}

Samernas folkhögskola

Protokoll Samernas folkhögskolas stiftelse, A1:1.

Protokoll styrelsen, A1:2.

Protokoll styrelsen, A1:3.

Protokoll arbetsutskottets möten, A1:7.

Skrivelser, E1:2.

Skrivelser, E1:12.

Skrivelser, E1:14.

Planeringar mm. Rennäringslinje F7 C:7.

Långa kurser F7 A:2

Långa kurser 7 A:4

Planeringar med mera (Långa kurser) F7 C:2.

Riksarkivet (RA)

Skolöverstyrelsen

Avdelningen för vuxenutbildningen

Folkhögskoleenheten

Rapporter över planerade kurser E5:183.

\section{Intervjuer}

Birgitta Östlund, 150421.

Ingwar Åhrén, 150413.

Per-Mikael Utsi, 150505.

\section{Tryckta källor och litteratur}

Aarseth, Bjørn. "Forsøk med reindriftsfag i skolen." I Samisk skolehistorie: Artikler og minner fra skolelivet i Sápmi 2, red. Svein Lund, Elfrid Boine och Siri Broch Johansen. Karasjok: Davvi girji, 2007.

Abendroth-Timmer, Dagmar och Eva-Maria Henning. "Plurilingualism and Multiliteracies: Identity Construction in Language Education." I Plurilingualism and Multiliteracies, red. Eva-Maria Henning och Dagmar Abendroth-Timmer. Frankfurt am Main: Peter Lang Publishing Group, 2014.

Abrams, Lynn. Oral History Theory. London: Routledge, 2010.

Bjørklund, Ivar. Sápmi - Becoming a Nation: The Emergence of a Sami National Community. Tromsø: Tromsø museum, 2000.

Burgman, Hans. "Folkhögskolan och den pedagogiska utvecklingen 1918-1968." I Svensk folkhögskola 100 år, del 3, red. Allan Degerman och Paul Terning. Stockholm: Liber, 1968.

Carbin Maria och Edenheim Sara. "The Intersectional Turn in Feminist Theory: A dream of a common language." European Journal of Women's Studies 20, nr. 3 (2013), 233-48. 
Clots-Figueras, Irma och Paolo Masella. "Education, Language and Identity." The Economic Journal 123, August (2013), 332-57.

Cocq, Coppélie. Mobilisering av minoritetsfolk: ČSV en etno-politisk rörelse bland samerna, jämförelse med négritude, en rörelse bland afrikaner. Umeå: Umeå universitet, 2000.

Elenius, Lars. "Ett nationellt metasystem för utbildning och fostran i Tornedalen." Nordic Journal of Educational History 1, nr 2 (2014), 63-85.

"Elever krever obligatorisk samisk." I Samisk skolehistorie: Artikler og minner fra skolelivet i Sápmi 2, red. Svein Lund, Elfrid Boine och Siri Broch Johansen. Karasjok: Davvi girji, 2007.

"Glimt fra kampen om samisk gymnas." I Samisk skolehistorie: Artikler og minner fra skolelivet i Sápmi 2, red. Svein Lund, Elfrid Boine och Siri Broch Johansen. Karasjok: Davvi girji, 2007.

Hall, Stuart. "När inträffade 'det postkoloniala?' Tänkande vid gränsen.” I Globaliseringens kulturer: Den postkoloniala paradoxen, rasismen och det mångkulturella samhälle, red. Chatarina Eriksson, Maria Eriksson Baaz och Håkan Thörn. Nora: Nya Doxa, 1999.

Hansson, Johan. "Svenska Missionssällskapet och Samernas folkhögskola." I De historiska relationerna mellan Svenska kyrkan och samerna: En vetenskaplig antologi, red. Daniel Lindmark och Olle Sundström. Skellefteå: Artos, 2016.

Hansson, Johan. "Educational Activities at the Sami Folk High School 1942-1982." Creative Education 6, no. 9 (2015), 880-97.

Jonzon, Bengt. "Till Sveriges samer." I Svenska missionssällskapet, Samernas folkhögskola. Luleå: Svenska missionssällskapet, 1942.

Larsson, Anna. Musik, bildning, utbildning: ideal och praktik i folkbildningens musikpedagogiska utbildningar 1930-1978. Göteborg: Makadam, 2007.

Ledman, Anna-Lill. Att representera och representeras: samiska kvinnor i svensk och samisk press 1966-2006. Umeå: Umeå universitet, 2012.

Lindkjølen, Hans. ”Kirkens rolle i samisk opplæring.” I Samisk skolehistorie: Artikler og minner fra skolelivet i Sápmi 1, red. Svein Lund, Elfrid Boine och Siri Broch Johansen. Karasjok: Davvi girji, 2005.

Lund, Svein. "'Den aller største milepær i næringens historie.”' I Samisk skolehistorie: Artikler og minner fra skolelivet i Sápmi 2, red. Svein Lund, Elfrid Boine och Siri Broch Johansen. Karasjok: Davvi girji, 2007a.

Lund, Svein. "'Den eneste i sitt slag i hele verden."' I Samisk skolehistorie: Artikler og minner fra skolelivet i Sápmi 2, red. Svein Lund, Elfrid Boine och Siri Broch Johansen. Karasjok: Davvi girji, 2007b.

Lund, Svein. "Fisk på land - ein dáža i samisk skole”. I Samisk skolehistorie: Artikler og minner fra skolelivet i Sápmi 2, red. Svein Lund, Elfrid Boine och Siri Broch Johansen. Karasjok: Davvi girji, 2007c.

Muntligt meddelande, Bokenskolan 2015-04-08.

Proposition 1990/91:82. Om folkbildning.

Said, Edward W. Orientalism. Stockholm: Ordfront, 2000.

Samernas utbildningscentrum. "Samernas" 70 år i samernas tjänst: Jubileumstidning. Jokkmokk: Sámij åhpadusguovdasj, 2013.

SFS 1991:977. Förordning om statsbidrag till folkbildningen.

SFS 2009:724. Lag om nationella minoriteter och minoritetsspråk. 
Sjögren, David. Den säkra zonen: Motiv, åtgärdsförslag och verksamhet $i$ den särskiljande utbildningspolitiken för inhemska minoriteter 1913-1962. Umeå: Umeå universitet, 2010.

SOU 1976:16. Folkhögskolan.

"Språkstriden på Samernas folkhögskola." Sáminuorra nr 1, 1979.

Stordahl, Vigdis. Same i den moderne verden: Endring og kontinuitet i et samisk lokalsamfunn. Karasjok: Davvi girji, 1996.

Terning, Paul. "Folkhögskolan och den pedagogiska utvecklingen 1918-1968." I Svensk folkhögskola 100 år, del 3, red. Allan Degerman och Paul Terning. Stockholm: Liber, 1968.

Tolvhed, Helena. "Intersektionalitet och historievetenskap." Scandia 76, nr 1. (2010).

Wallmark, Lennart. Samernas folkhögskola: Sorsele: redogörelse för läsåret 19441945. Svenska missionssällskapet: Sorsele, 1945.

Wallmark, Lennart. Samernas folkhögskola: Jokkmokk: redogörelse för läsåret 19501951. Svenska missionssällskapet: jokkmokk, 1951.

Wallmark, Lennart. Samernas folkhögskola: Jokkmokk: redogörelse för läsåret 19551956. Svenska missionssällskapet: Jokkmokk, 1956.

Wallmark, Lennart. Samernas folkhögskola: Jokkmokk: redogörelse för läsåret 19651966. Svenska missionssällskapet: Jokkmokk, 1966.

Wallmark, Lennart. Samernas folkhögskola: Jokkmokk: redogörelse för läsåret 19691970. Svenska missionssällskapet: Jokkmokk, 1970.

Wallmark, Lennart. Samernas folkögskola: Jokkmokk: redogörelse för läsåret 19681969. Svenska missionssällskapet: Jokkmokk, 1969.

Wallmark, Lennart. "Samernas folkhögskola, dess tillkomst och idé." I Bland Sveriges Samer: Årskrift Svenska missionssällskapet Kyrkan och samerna 1948-1949. Umeå: Svenska missionssällskapet, 1949.

Åhrén, Christina. Är jag en riktig same?: En etnologisk studie av unga samers identitetsarbete. Umeå: Umeå universitet, 2008.

Östlund, Birgitta. "På en minnepinne", "Samernas" 70 år i samernas tjänst: Jubileumstidning. Jokkmokk: Sámij åhpadusguovdasj, 2013.

\section{Webresurser}

Aftenposten (2011). "Ville bruke soldater i Alta-aksjon". http://www.aftenposten.no/ nyheter/iriks/Ville-bruke-soldater-i-Alta-aksjon-6393917.html (hämtad 9 april, 2015).

Design og handverk. http://design-handverk.no/ (hämtad 12 maj 2015).

Historik Samernas folkhögskola/utbildningscentrum. http://www.samernas.se/ om-samernas/historik/ (hämtad 4 februari 2016).

Regeringens proposition 1990/91:82. https://www.riksdagen.se/sv/Dokument-Lagar/Forslag/Propositioner-och-skrivelser/om-folkbildning_GE0382/?html=true (hämtad 4 februari 2016).

Riksdagens protokoll 1990/91:129. https://www.riksdagen.se/sv/Dokument-Lagar/ Kammaren/Protokoll/_GE09129/ (hämtad 4 februari 2016).

Saba, Isak. "En sång - ett folk." http://www.samer.se/1149 (hämtad13 april 2015).

Utbildningsutskottets betänkande, 1990/91:UbU18. https://www.riksdagen.se/ sv/Dokument-Lagar/Utskottens-dokument/Betankanden/Folkbildningen_ GE01UbU18/ (hämtad 4 februari 2016). 